\title{
Pyramidal structures: The evidence from Poland
}

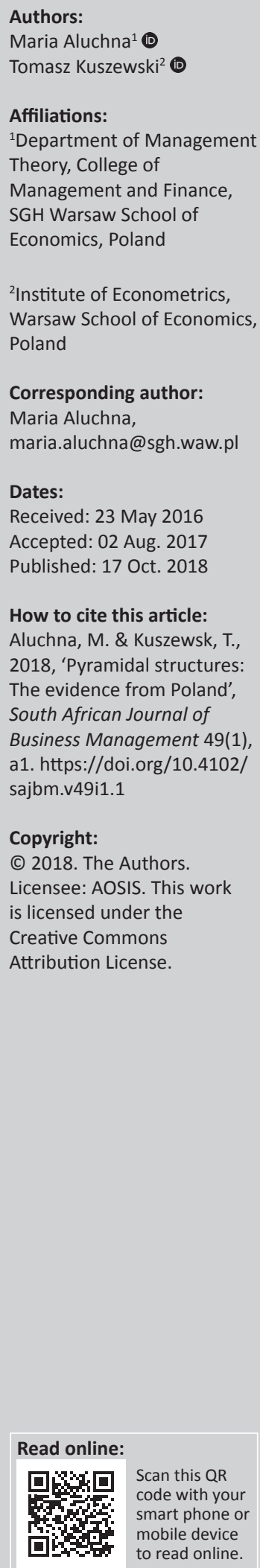

Background: Pyramidal structures are a specific ownership pattern adopted worldwide, which increases the power of controlling shareholder allowing for lower capital investment. Existing studies still fail to explain the reasons for their adoption in companies.

Objectives: The goal was to explore pyramidal structures as a newly developing ownership pattern in an emerging market and to identify firm-level characteristics that determine their adoption. Specifically, we tested three alternative rationales - control leverage, venture and governance - which provide competitive arguments to explain the formation of pyramids.

Method: Adopting a linear panel model, we examined a sample of 168 non-financial companies listed on the Warsaw Stock Exchange over the period 2010-2014.

Results: The adoption of a pyramid was associated with higher ownership concentration and with lower ownership concentration by a shareholder coalition. There was also a positive relationship between the use of a pyramid and company operation within a business group as well as a smaller number of affiliated companies. We identified a positive link between the use of a pyramid and investment by financial investors.

Conclusion: Pyramids serve as a tool for expansion of the business group, important in an environment of costly access to external capital because the business group enables the raising of capital and lowers the risk posed to a new firm. This confirmed the venture and governance rationales, whereas we did not find evidence for the control leverage hypothesis. Governance in a pyramid by financial entities discourages investment by portfolio-oriented financial investors.

\section{Introduction}

Ownership structure is understood as the relative and absolute involvement of distinct shareholders in company stockholdings and is expressed in terms of the stake (proportion and number) of controlled shares. It represents the concentration of ownership and control as well as the positions of different shareholder types. Existing studies on ownership structure, its dynamics and characteristics help illustrate the management style, the decision-making process and the strategic development paths taken by companies (Demsetz \& Lehn 1985). Research reveals that shareholders have different interests and goals which determine their behaviour and investment strategies at the company level (Castañer \& Kavadis 2013; Combs 2008; van Essen et al. 2015). Specifically, the existing literature in management and finance indicates that shareholder structure influences company growth and development, being a crucial determinant for the company's operation horizon (Clarke 2014), its strategy (Castañer \& Kavadis 2013; van Essen et al. 2015), investment and profit distribution (Shleifer \& Vishny 1997), leadership (Combs 2008) and human resource practice (van Essen et al. 2012).

Comparative analysis reveals distinct types of ownership structure and patterns of corporate control which offer both favourable environments and structural limitations for company's strategic development. For instance, the dispersed ownership that is a characteristic of large firms and Anglo-Saxon companies allows for risk diversification, profit sharing and flexible funds allocation. It also secures the raising of substantial capital for company growth and development. However, companies characterised by dispersed ownership are prone to experience principalagent conflicts between executives and shareholders (Fama \& Jensen 1983; Jensen \& Meckling 1976; Shleifer \& Vishny 1997). In addition, portfolio-oriented financial investors prefer the distribution of created value (in the form of stock repurchase and higher share prices or dividend payouts) to having numerous shareholders and may limit investment in research and development (R\&D) and company-specific skills (Carlin \& Mayer 2003). Concentrated ownership, as associated 
with family control and the involvement of corporate owners, is evident in continental Europe, Latin America and Asia (Morck 2005; 2009), but it also remains the prevalent feature of emerging markets (Le, Kroll \& Walters 2010). The concentration of ownership results in (or is reinforced by) additional mechanisms of leveraging control. Thus, concentrated control is not only caused by a simple majority stake held by the dominant shareholder, but also strengthened by the adoption of dual class shares and pyramidal structures (Almeida \& Wolfenzon 2006; Morck 2009; Zattoni 1999). On the level of business management, concentration of ownership and control is associated with larger private benefits, a larger scope for diversification and investments in $R \& D$, and company-specific skills. Although it has a positive impact on growth stability, it may result in overinvestment in mature industries and limit flexible resources allocation (Carlin \& Mayer 2003).

The identification of ownership and control structure helps the understanding of business management and company development. Comparative analysis reveals that patterns of ownership and control emerge in response to institutional arrangements and prevail for as long as they offer an effective structure and decision-making context to generate profits (Demsetz 1983). With the growing interest in emerging economies, more attention has recently been given to arrangements which leverage control, including pyramidal structures, shareholder coalition, adoption of dual class shares and statutory provisions such as qualified majority or personal authorisation rights (Barontini \& Caprio 2005; Sauerwald \& Peng 2013). Studies on emerging markets depict different and more complex patterns of ownership and control than those noted in Anglo-Saxon economies and show that the emergent shareholder structure represents a dynamic reaction to the regulatory and institutional context. The ownership and control logic exemplifies the given corporate-institutional puzzle.

In this article, we draw upon the development of pyramidal structures in the context of an emerging market and identify firm-level characteristics that determine their adoption. This article is driven by two motivations. Firstly, the formation of pyramidal structures still remains an unexplored phenomenon in the literature related to ownership and control (Almeida et al. 2011). The suggested logic behind the emergence of pyramidal ownership refers to risk diversification (Almeida \& Wolfenzon 2006), tax optimisation (Morck 2005), control leverage (Villalonga \& Amit 2009), or the realisation of private benefits at the expense of minority shareholders (Bertrand, Mehta \& Mullainathan 2002). However, so far no formal theory has been put forward to explain why pyramids are adopted, why they are used more often than other similar mechanisms (such as dual class shares) and why they are formed in countries at differing stages of economic and social development. Secondly, the emergence of pyramids appears to be particularly intriguing in the case of developing or transition economies that represent dynamically evolving institutional environments characterised with significant ownership turnarounds. The review of the existing literature shows that there is a gap in pyramid formation in transition economies such as Central and Eastern Europe (CEE). The CEE region, following the unprecedented institutional transition which took place there, constitutes an unique kind of natural experiment for observing the ownership change that took the form of extensive privatisation schemes of former state-owned enterprises (SOEs) and the dynamic emergence of newly founded firms (Hardi \& Buti 2012).

We intend to explore the adoption of pyramids by addressing three alternative rationales - control leverage, venture set-up and governance - which provide alternative explanation for the formation of these structures. Based on review of the existing literature, we aim to test the use of pyramids in relation to ownership and control, in addition to operation within a business group. Adopting a panel study, we examine a sample of 168 non-financial companies listed on the Warsaw Stock Exchange (WSE) during the period 2010-2014. This article contributes to existing knowledge in two ways. Firstly, it fills a gap in the literature on the dynamics of ownership structure in emerging economies. We document the significant frequency of the use of pyramidal structures in Polish listed companies that has emerged within the last 10-15 years. Secondly, this article contributes to an understanding of the logic behind the adoption of pyramidal structures. We identify links between the formation of a pyramid and internal company characteristics such as concentration of ownership and control, ownership by financial investors, operation within a business group and the number of affiliated companies in the group. Specifically, we argue that pyramids serve as a tool supporting the development of companies within the business group, thus confirming the venture and governance rationale, whereas we do not find evidence for the notion of control leverage.

This article is organised as follows. The first section discusses alternative rationales behind the adoption of pyramids. The second section outlines the evolution of the ownership structure in the context of the emerging market of Poland. The third section reports the results of a linear panel model on the pyramidal structures in companies listed on the WSE and discusses their adoption with respect to the firm characteristics. Final remarks are presented in the conclusion section.

\section{Pyramids as a specific ownership pattern}

\section{The definition of a pyramid}

Ownership concentration is used as a tool to exert control over company assets and serves as an important governance mechanism (Shleifer \& Vishny 1997). However, the concentration of shares represents merely one possible mechanism for increasing control, whereas the same effect can also be achieved or strengthened by the concentration of 


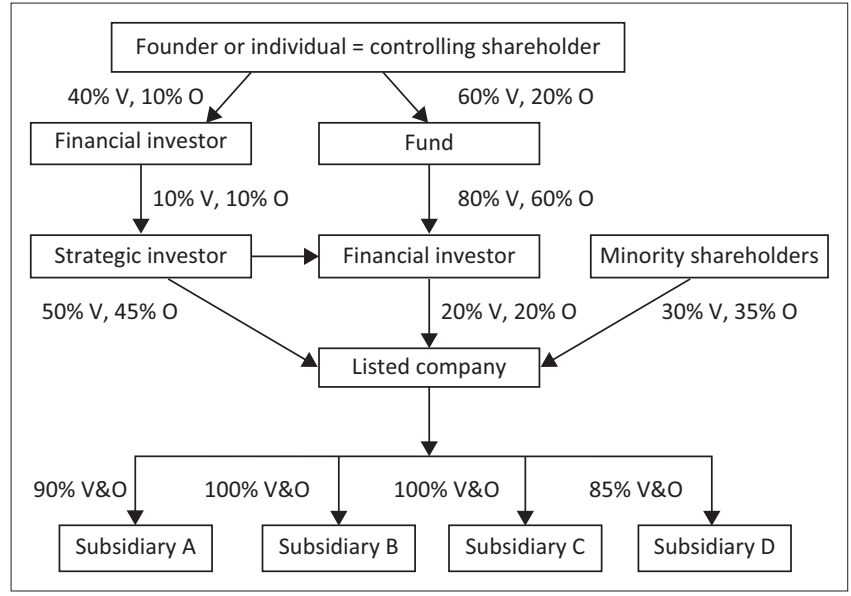

$\mathrm{V}$, votes; O, ownership.

FIGURE 1: A model of a pyramid.

voting rights. Comparative analysis reveals that ownership concentration may be associated with the control leverage provided by the use of pyramidal structures (Zattoni 1999) and dual class shares (Harris \& Raviv 1988), adopted separately or jointly (Barontini \& Caprio 2005). Pyramids consist of multiple layers of ownership relationships characterised by mutual cross-shareholdings (Patel, Balic \& Bwakira 2002; Perkins, Morck \& Young 2014). Hence, pyramidal structures are formed by a number of companies linked with capital ties, strengthened by interlocking directorates and tied with financial and investment policies which constitute relations of control (Zattoni 1999). The ultimate owner maintains control over a large group of companies via indirect ownership (Bertrand et al. 2002), which lowers the risk from concentrated ownership (Demsetz \& Lehn 1985). Figure 1 presents the model of a pyramidal structure.

As shown in Figure 1, different investors are involved in the pyramidal structure representing affiliated, associated and participative shareholdings (Renneboog 1998). Some of these entities may be under the control of an individual or a single investor who de facto controls the group via direct or indirect links (Morck 2005; Zattoni 1999). The power exerted by the controlling shareholder is calculated as the product of the multiplication of votes held at different levels of the pyramid and indicates its ultimate control level (Renneboog 1998; 2000). Certain legal regimes, for instance in South Korea, allow for reciprocal ownership interlocks that strengthen the density of the links and increase the percentage of internal ownership (Morck 2005). As a result, it also worsens the transparency of the ownership structure and decisionmaking (Almeida \& Wolfenzon 2006; Zattoni 1999).

In a pyramid, the dominant shareholder controls the process of decision-making via the controlling (holding) company over the portfolio firms out of which many may be listed (Cuervo-Cazzura 2006). The main listed company is located at the apex of the pyramid and is controlled via the chain of subsidiaries with many not reporting any operational activity but serving as financial and holding vehicles. The model of the pyramid offered by Zattoni (1999) shows that if the largest shareholder intends to finance a company with equity (50\%) and debt (50\%), he needs to main a control stake of $51 \%$. Adopting this technique to companies at every subsequent level of the pyramid, the largest shareholder maintains control of the chain of firms, minimising his personal investment. This effect is more powerful if the controlling stake is lower or the debt is higher, while control by the dominant shareholder is also ensured with the use of dual class shares and mutual shareholdings between different levels in the pyramid. 'Obviously, this mechanism works only if the controlling shareholder succeeds in convincing a large number of savers to buy shares in firms belonging to the group' (Zattoni 1999:42). In effect, the pyramidal structure allows the controlling shareholder to exert control over profit distribution, which takes the form of related party transactions and transfers of funds amongst affiliated entities (Almeida \& Wolfenzon 2006; Pursey, Heugens \& Zyglidopoulos 2008). As the group interest dominates over the goals of the individual company, these transactions may take the form of tunnelling and may be conducted at the expense of minority investors (Bany-Ariffin, Nor \& McGowan 2010; Morck, Wolfenzon \& Yeung 2004).

\section{The theory of pyramids}

Reported in numerous countries pyramids remain the prevalent mechanism of control leverage, yet the process of their emergence is not sufficiently understood (Morck 2004). As argued by Almeida and Wolfenzon (2006:2638), 'no formal theory explains' the existence of pyramids and the motivation that drives companies and investors to choose this ownership pattern. Moreover, studies do not justify the prevalence of pyramids in the process of firms' strategic development. The gaps in the existing literature refer to both the understanding of the external context and the internal characteristics of the firm that stimulate the formation of pyramids. Firstly, the existing literature fails to demonstrate why pyramids have emerged in different institutional and regulatory regimes. Pyramids are found in emerging economies such as India (Ramachandran \& Marisetty 2009), South Korea (Almeida et al. 2011), China (Lio \& Sun 2004), Thailand (Bunkanwanicha, Fan \& Wiwattanakantang 2008), Russia (Radygin 2007), Ukraine (Paskhaver \& Verkhovodova 2007), Mexico, Brazil, Chile, Peru, Argentina, Brazil (Perkins et al. 2014). The compensation for institutional voids offered to explain the formation of pyramids in emerging markets fails to be useful in many developed economies such as Belgium (Renneboog 1998), Sweden (Holmen \& Högfeldt 2005), Italy, France and Canada (Morck 2004), where pyramids are widely reported. Studies do not provide sufficient arguments to understand the absence of pyramids in Anglo-Saxon economies either (Morck 2009). Secondly, the role of internal company characteristics that stimulate the emergence of pyramids is not clearly understood (Morck 2004; Renneboog 1998, 2000). Specifically, studies fail to explain why pyramids prevail over the use of the dual class shares having the same effect for increasing control (Almeida \& Wolfenzon 2006; Zattoni 1999), or why they are adopted in family controlled companies (Morck 2005). 
Generally, the literature offers three rationales to explain the formation of pyramids - the control approach, the venture approach and the governance approach. We aim to test which approach prevails in the context of an emerging market where pyramidal structures are a novel ownership arrangement. Below, we formulate hypotheses testing all three notions.

According to the control rationale, the construction of a pyramid is viewed as a mechanism of control leverage (Villalonga \& Amit 2009) and a separation of control and cash flow rights (i.e. participation in profit) (Bebchuk, Kraakman \& Trantis 2000; Claessens et al. 2002; Riyanto \& Toolsema 2008). Pyramids are formed to increase or at least maintain a certain level of control over decision-making while minimising personal investment. Every subsequent level in the pyramid allows control to be maintained while simultaneously decreasing the proportion of generated profit (Bertrand et al. 2002). This separation of control and cash flow rights increases leverage and lowers the risk from having significant stake in ownership (Zattoni 1999). The wedge between control and cash flow rights is illustrated by the wide range of corporate decisions concerning investments, the size of the company and its scope of operations (Villalonga \& Amit 2006). In this approach, the use of pyramids is driven by the motivation to minimise capital involvement and increase control over the companies. The control motivation logically requires a lower ownership concentration (Morck 2009) and the use of possible shareholder coalitions (Bianchi \& Bianco 2006). Testing the control leverage argument as the driver for the adoption of pyramids, we formulate the following hypotheses:

H1: The adoption of a pyramid is associated with lower ownership concentration.

$\mathrm{H} 2$ : The adoption of a pyramid is associated with higher ownership by shareholder coalitions.

The alternative perspective suggests that pyramids are formed because they offer an efficient environment, and the ability to access the entire stockholding and to secure internal funds for setting up new ventures without the need to raise external capital (Khanna \& Yafeh 2005). Almeida and Wolfenzon (2006) identify the venture rationale mostly in the case of family controlled companies. The formation of a pyramid, seen as a tool for exerting control over a firm through a chain of ownership relations, is driven by the motivation 'to access all retained earnings of a firm it already controls, to set up a new firm, and to share the new firm's non-diverted payoff with shareholders of the original firm' (Almeida \& Wolfenzon 2006:2637). According to this venture approach, pyramidal structures become a tool for expansion of the business group, particularly attractive in an environment of costly access to external capital (Almeida et al. 2011; Schulze et al. 2001). In the context of the emerging markets, the use of pyramidal structures allows for flow of capital at low cost via related party transactions and capital and tax optimisation within the entity. Companies which adopt pyramids are able to enjoy all the benefits within a more complex organisational structure of a business (corporate) group (Radygin 2007). In order to test the venture argument, we formulate the following hypotheses, $\mathrm{H} 3$ and $\mathrm{H} 4$ :

H3: The adoption of a pyramid is associated with company operation as a business group as opposed to a stand-alone company.

H4: The adoption of a pyramid is associated with a smaller number of affiliated companies in a business group.

Finally, the governance argument provides a competitive explanation for the emergence of pyramids. According to this rationale, pyramids lower transaction costs and offer effective governance arrangements (Edwards \& Weichenrieder 2004). Several studies provide evidence suggesting that pyramids do not destroy shareholder value but simply serve as a tool used by founders for exerting governance and control over the companies (Holmen \& Högfeldt 2005; Morck et al. 2004). Pyramids are a device that ensures control over the chain of company assets and secures the interests of the controlling shareholder (Villalonga \& Amit 2009). This also becomes beneficial for minority investors. The chain of multi-level cross shareholdings enables the blockholder to maintain control and influence over decision-making across the group of companies (Bebchuk et al. 2000; Morck 2004; Villalonga \& Amit 2009; Zattoni 1999). The chain of cross shareholdings simplifies strategic decision-making, investment policy and profit distribution provided by a single entity. As a consequence, pyramids are owned by large financial investors controlled by founders and families, who appoint directors on corporate boards of affiliated companies (BanyAriffin et al. 2010; Morck 2005). Because of the risk of expropriation and the realisation of private benefits by controlling shareholders, this implies the emergence of a closed structure and a high ratio of inner ownership (Su 2015) as well as a relative absence of portfolio-oriented financial investors. Following on from the governance rationale, we formulate hypotheses $\mathrm{H} 5$ and H6:

H5: The adoption of a pyramid is associated with larger ownership by financial investors.

H6: The adoption of a pyramid is associated with smaller ownership by portfolio-oriented financial investors.

\section{The emerging patterns of ownership in Poland}

The systemic transition that started in CEE in 1989 represents a dramatic institutional change from socialism to democracy and from central planning to market economy (Coffee 1999). The system prior to 1989, characterised as 'destroyed capitalism' (Balcerowicz 1995), was based on state control and the paradigm of citizens' ownership. Because of the lack of effective 
monitoring, reporting and performance-driven decisionmaking, the central planning doctrine proved to be highly inefficient in rights, incentives and assets allocation (Murrell 1999). The processes of decision-making and performance monitoring are heavily embedded in the shareholder structure. Thus, the transition, which aimed at the implementation of market-driven decisions for resource allocation and the adoption of economic efficiency principles as a means of performance evaluation, required significant ownership reforms. In effect, over the last 28 years, companies in transition economies have experienced a significant turnaround of ownership structure, resulting from either privatisation schemes (Wang \& Judge 2012) or the emergence of a new structural arrangement in the case of newly founded firms (Dobak 2008). This evolution is visible in the CEE region as well as in China, India and countries in Southeast Asia. Such a posttransition environment offers a unique opportunity for identifying the dynamics of shareholder structure and for exploring the emergence of new ownership and control patterns.

In the case of Poland, the ownership shift has been based on four main programmes - the so-called case-by-case privatisation, mass privatisation, liquidation and the rise of de novo firms. Firstly, the case-by-case privatisation took the form of the takeover of former SOEs by industry or individual investors, either via direct sale or via sale of the dominant stake in combination with an IPO on the stock exchange. This scheme included over 2300 companies of which 1560 were covered by the employee stock ownership plans (Ruszkowski 2010). Secondly, the politically delayed mass privatisation programme was carried out by National Investment Funds (NFI) and covered 512 companies. This scheme engendered costly and complex structures and was found to be the least efficient privatisation programme, and the NFI portfolio companies were either sold to investors or liquidated. Thirdly, over 1900 firms were found to be structurally and permanently inefficient and were put into liquidation.

In summary, according to the report by the Ministry of Treasury (2016) of 8453 SOEs operating as of 31 December 1990, 6003 SOEs went through some form of ownership restructuring between 01 August 1990 and 31 December 2015, with the following breakdown:

- 1756 companies were incorporated.

- 2308 companies were privatised directly (sale).

- 1939 companies were liquidated.

- 1301 companies controlled by the Ministry of Treasury were covered by:

- mass privatisation scheme (NFI) - 512 SOEs

- indirect privatisation - 543 SOEs

- debt conversion - 127 SOEs

- free disposal of shares for local governments - 73 SOEs

- other programmes - 46 SOEs.

Finally, the picture of ownership structure has significantly transformed with the growth of newly established companies controlled by founders. The trend strengthened with the economic development following Poland's accession to the European Union in May 2004. Both the privatisation of SOEs and the emergence of de novo firms contributed to the development of the stock market. Currently, the WSE hosts 487 companies with an estimated total of $€ 260$ billion in capitalisation, accounting for ca. $55 \%$ of gross domestic product (GDP), ${ }^{1}$ whereas the New Connect Market (Alternative Market System) has expanded rapidly and currently lists 403 companies.

In short, the concentrated and state control of enterprises in socialistic Poland has been replaced with the concentrated ownership and control by industry and private investors in the context of a post-transition, emerging economy. New patterns of pyramidal ownership and dual class shares have developed from scratch, becoming dominant mechanisms for exerting control leverage within listed companies. Such patterns were formed as a reaction to the new institutional environment and to market opportunities. Studies show that Polish companies reveal a significant concentration of ownership, characterised by an average stake of the largest shareholder estimated at $41 \%$ of shares (Aluchna 2007; Urbanek 2009). The largest group of companies with respect to their historical origin is represented by privately founded firms which were established after 1990 and, in the process of development, were listed on the stock exchange. In terms of investor identity, domestic individuals are the most frequent majority shareholders, followed by domestic and foreign industry investors (Urbanek 2009). Approximately $80 \%$ of listed companies form business groups, adopting the form of holdings with the dominant parent and affiliated companies, some of which are financial vehicles. Blockholders are also prone to adopt mechanisms increasing the concentration of votes, including dual class shares and shareholders' coalition agreements; mechanisms increasing the power of voting rights, such as qualified majority or personal authorisation rights; and mechanisms for leveraging control with the use of pyramids. Thus, the Polish perspective concerning ownership and control corresponds with the post-transition and emerging market characteristics based upon the role of hierarchies (Bedo \& Acs 2007; Hardi \& Buti 2012). As noted by Berglöf and Claessens (2006), emerging and transition economies are characterised by ownership concentration. As majority shareholders are involved in governance and management, companies do not reveal the separation of ownership and control. The control role is played by blockholders, whereas the monitoring function of external mechanisms (stock markets and markets for corporate control) remains significantly weaker (Berglöf \& Claessens 2006). The board is unlikely to be influential when the controlling owner can hire and fire board members, while its potential for monitoring remains unexploited and structurally limited.

1.As for 19 June 2017, www.gpw.pl, www.newconnect.pl, www.fese.org 


\section{Research}

\section{Sample and variables}

The initial sample covers data from 200 non-financial companies listed on the WSE during the period 2010-2014 and is constructed to ensure a balanced representation of the overall population of listed firms. Data were collected from the EMIS base and combined with information from annual reports, consolidated financial statements and supplementary information published on company websites. The information on the characteristics of pyramidal structures, the number of levels and the number and identity of the controlling entities and ultimate shareholders was hand collected from the National Court Register (Krajowy Rejestr Sądowy, KRS).

TABLE 1: Description of variables used.

\begin{tabular}{|c|c|c|}
\hline Variable & Variable description & Variable type \\
\hline PYRAMIDa & The adoption of a pyramid (1-yes, 0 -no) & Qualitative, binary \\
\hline RDIVID & Dividend yield (\%) & Quantitative, real \\
\hline EMPT & Employment & Quantitative, real \\
\hline SUPBOARD & Size of the supervisory board & Quantitative, integer \\
\hline BUSGROUPa & $\begin{array}{l}\text { Functioning within the business group } \\
\text { (1-yes, 0-no) }\end{array}$ & Qualitative, binary \\
\hline COMPS $^{a}$ & Number of firms in business group & Quantitative, integer \\
\hline OSHAROVO & $\begin{array}{l}\text { Adoption of one share one vote rule } \\
\text { (1-yes, 0-no) }\end{array}$ & Qualitative, binary \\
\hline IDENTITY & Type of the largest shareholder & Quantitative, integer \\
\hline LARGSHARE $^{a}$ & Stake of the first largest shareholder (\%) & Quantitative, real \\
\hline ALARGSHARE & $\begin{array}{l}\text { Stake of the first largest shareholder in } \\
\text { case of a coalition }(\%)\end{array}$ & Quantitative, real \\
\hline FINSHARE $^{a}$ & Stake of financial investors (\%) & Quantitative, real \\
\hline FINPORTSHARE & $\begin{array}{l}\text { Stake by portfolio-oriented financial } \\
\text { investors }(\%)\end{array}$ & Quantitative, real \\
\hline ASSETSCON ${ }^{a}$ & Assets (million PLN) & Quantitative, real \\
\hline TOTEQCON & Equity (million PLN) & Quantitative, real \\
\hline INCNETCON & Revenue (million PLN) & Quantitative, real \\
\hline PROFITNETCON & Net income (million PLN) & Quantitative, real \\
\hline LTLIABCON & Long term debt (million PLN) & Quantitative, real \\
\hline STLIABCON & Short term debt (million PLN) & Quantitative, real \\
\hline SHARESCON & Shares circulating (100 000 shares) & Quantitative, real \\
\hline PROFITPSCON & Income per share (PLN) & Quantitative, real \\
\hline ROACON & ROA (\%) & Quantitative, real \\
\hline ROECON & ROE $(\%)$ & Quantitative, real \\
\hline
\end{tabular}

a,Variables used for the construction of the final model; PYRAMID, adoption of a pyramid (1-yes, 0-no); SUPBOARD, the size of the supervisory board; BUSGROUP, represents that functioning within the business group (1-yes, 0-no); COMPS, the number of firms in busines group; LARGSHARE, represents the stake of the first largest shareholder (\%); ALARGSHARE, represents the stake of the first largest shareholder in case of a coalition (\%); FINSHARE, the stake of financial investors (\%); FINPORTSHARE, the stake by portfolio-oriented financial investors (\%); ASSETSCON, company assents (in million PLN); TOTEQCON, company equity (in million PLN).
In order to model the adoption of pyramids, we use crosssectional and observational data. The sample is constructed not on a random but purposive basis; hence, the estimations may be burdened with the kind of selection sample error that often occurs in micro-data research. For the purpose of the research, we limit the further statistical discussion to essential information. The panel constructed for the period 2010-2014 covered 181 firms with 192 observations for 2010, 199 for 2011, 196 for 2012, 191 for 2013 and 188 for 2014. As statecontrolled companies were excluded from the analysis, the final sample covered 840 observations on 168 firms.

As shown in Table 1, we use quantitative and qualitative data. Quantitative data are measured on the continuous measurement scale, whereas qualitative data are measured on a non-continuous measurement scale, which affects the estimation of the model parameters and their subsequent interpretation. The ceteris paribus rule cannot be properly adopted (Wooldridge 2002). The collected data set is larger than the variables used for the construction of the final model (marketed with * sign). Other variables, not included in the model, are statistically insignificant.

We use LARGSHARE, ALARGSHARE, BUSGROUP, COMPS, FINSHARE and FINPORTSHARE as explanatory variables, whereas SUPBOARD, ASSETSCON and TOTEQCON serve as control variables. Table 2 reveals the variables and their values as used in the econometric model.

With respect to the value of PYRAMID variable, the sample is balanced. Companies adopting pyramidal structures constitute ca. $52 \%$ of the sample in 2010 and $62 \%$ in 2013. In absolute numbers they represent between 88 and 104 firms. Approximately $81 \%-85 \%$ (140) of firms function as business groups. The average values of SUPBOARD, LARGSHARE and FINPORTSHARE remain stable over the analysed period. The values of other variables reveal a slight increase. The value distribution of integer and continuous scale variables is shown in Table 3 with respect to their measuring positions (mean, minimum, Q1, median, Q3, maximum).

As shown in Table 3, the values of the median, Q1, Q3 and the mean indicate an asymmetric distribution of variables.

TABLE 2: Value of variables used in the analysis

\begin{tabular}{|c|c|c|c|c|c|}
\hline Variable & 2010 & 2011 & 2012 & 2013 & 2014 \\
\hline PYRAMID & 0.52 & 0.57 & 0.60 & 0.62 & 0.61 \\
\hline SUPBOARD & 5.74 & 5.80 & 5.76 & 5.76 & 5.75 \\
\hline BUSGROUP & 0.81 & 0.83 & 0.84 & 0.85 & 0.84 \\
\hline COMPS & 8.30 & 9.49 & 9.56 & 9.96 & 10.99 \\
\hline LARGSHARE & 39.01 & 39.52 & 39.15 & 38.60 & 39.07 \\
\hline ALARGSHARE & 41.77 & 42.90 & 42.82 & 41.32 & 41.36 \\
\hline FINPORTSHARE & 9.13 & 9.02 & 9.49 & 10.05 & 10.50 \\
\hline ASSETSCON & 923.91 & 1040.65 & 980.60 & 970.90 & 1142.20 \\
\hline TOTEQCON & 451.69 & 487.93 & 473.16 & 478.86 & 539.72 \\
\hline
\end{tabular}

PYRAMID, adoption of a pyramid (1-yes, 0-no); SUPBOARD, the size of the supervisory board; BUSGROUP, represents that functioning within the business group (1-yes, 0-no); COMPS, the number of firms in business group; LARGSHARE, represents the stake of the first largest shareholder (\%); ALARGSHARE, represents the stake of the first largest shareholder in case of a coalition (\%); FINSHARE, the stake of financial investors (\%); FINPORTSHARE, the stake by portfolio-oriented financial investors (\%); ASSETSCON, company assents (in million PLN); TOTEQCON, company equity (in million PLN). 
TABLE 3: Values of measuring positions of variables on the continuous scale.

\begin{tabular}{|c|c|c|c|c|c|c|}
\hline Variable & Mean & Minimum & Q1 & Median & Q3 & Maximum \\
\hline SUPBOARD & 5.8 & 4.0 & 5.0 & 5.0 & 6.0 & 14.0 \\
\hline COMPS & 9.7 & 0.0 & 2.0 & 6.0 & 11.0 & 121.0 \\
\hline LARGSHARE & 39.1 & 5.0 & 23.0 & 33.0 & 57.0 & 97.0 \\
\hline ALARGSHARE & 42.0 & 0.0 & 24.3 & 41.0 & 59.0 & 97.0 \\
\hline FINSHARE & 12.2 & 0.0 & 0.0 & 9.0 & 19.0 & 80.0 \\
\hline FINPORTSHARE & 9.6 & 0.0 & 0.0 & 7.0 & 16.0 & 73.0 \\
\hline TOTEQCON & 486.3 & -843.5 & 46.1 & 121.3 & 374.9 & 14634.0 \\
\hline
\end{tabular}

SUPBOARD, the size of the supervisory board; COMPS, the number of firms in business group; LARGSHARE, represents the stake of the first largest shareholder (\%); ALARGSHARE, represents the stake of the first largest shareholder in case of a coalition (\%); FINSHARE, the stake of financial investors (\%); FINPORTSHARE, the stake by portfolio-oriented financial investors (\%); ASSETSCON, company assents (in million PLN); TOTEQCON, company equity (in million PLN).

TABLE 4: Correlation matrix of selected variables.

\begin{tabular}{|c|c|c|c|c|c|c|c|c|c|c|}
\hline Variable & PYRAMID & SUPBOARD & BUSGROUP & COMPS & LARGSHARE & ALARGSHARE & FINSHARE & FINPORTSHARE & ASSETSCON & TOTEQCON \\
\hline PYRAMID & 1.00 & $0.28 \mathrm{~V}$ & $0.48 \mathrm{H}$ & $0.32 \mathrm{~V}$ & $0.53 \mathrm{E}$ & $0.55 \mathrm{E}$ & $0.30 \mathrm{E}$ & $0.26 \mathrm{E}$ & $0.99 E$ & $0.99 E$ \\
\hline SUPBOARD & - & 1.00 & $0.17 \mathrm{~V}$ & $0.29 \mathrm{~V}$ & $0.45 \mathrm{E}$ & $0.45 \mathrm{E}$ & $0.33 \mathrm{E}$ & $0.31 \mathrm{E}$ & $0.99 \mathrm{E}$ & 0.99E \\
\hline BUSGROUP & - & - & 1.00 & $0.99 \mathrm{~V}$ & $0.51 \mathrm{E}$ & $0.53 \mathrm{E}$ & $0.31 \mathrm{E}$ & $0.29 \mathrm{E}$ & $0.99 \mathrm{E}$ & $0.99 \mathrm{E}$ \\
\hline COMPS & - & - & - & 1.00 & $0.44 \mathrm{E}$ & $0.44 \mathrm{E}$ & $0.34 \mathrm{E}$ & $0.29 \mathrm{E}$ & $0.99 E$ & $0.99 \mathrm{E}$ \\
\hline LARGSHARE & - & $0.18 \mathrm{E}$ & $0.15 E$ & $0.29 \mathrm{E}$ & 1.00 & $0.91 \mathrm{P}$ & $-0.22 \mathrm{P}$ & $-0.28 \mathrm{P}$ & $0.05 \mathrm{P}$ & $0.03 P$ \\
\hline ALARGSHARE & - & $0.16 \mathrm{E}$ & $0.18 \mathrm{E}$ & $0.29 \mathrm{E}$ & - & 1.00 & $-0.26 \mathrm{P}$ & $-0.32 \mathrm{P}$ & $0.01 \mathrm{P}$ & $-0.01 P$ \\
\hline FINPORTSHARE & - & $0.21 \mathrm{E}$ & $0.17 \mathrm{E}$ & $0.39 \mathrm{E}$ & - & - & - & 1.00 & $0.03 \mathrm{P}$ & $0.04 \mathrm{P}$ \\
\hline ASSETSCON & - & $0.79 E$ & $0.15 E$ & $0.59 \mathrm{E}$ & - & - & - & - & 1.00 & $0.95 P$ \\
\hline TOTEQCON & - & $0.80 \mathrm{E}$ & $0.13 \mathrm{E}$ & $0.55 \mathrm{E}$ & - & - & - & - & - & 1.00 \\
\hline
\end{tabular}

P, Pearson's coefficient; V, V-Cramer coefficient; H, Phi coefficient; E, Eta coefficient; PYRAMID, adoption of a pyramid (1-yes, 0-no); SUPBOARD, the size of the supervisory board; BUSGROUP, represents that functioning within the business group (1-yes, 0-no); COMPS, the number of firms in business group; LARGSHARE, represents the stake of the first largest shareholder (\%); ALARGSHARE, represents the stake of the first largest shareholder in case of a coalition (\%); FINSHARE, the stake of financial investors (\%); FINPORTSHARE, the stake by portfolio-oriented financial investors (\%); ASSETSCON, company assents (in million PLN); TOTEQCON, company equity (in million PLN).

For instance, ASSETSCON is skewed to the right, meaning that companies with low values of ASSETSCON are more frequently present in the research sample than those with high values. In other words, the right tail is longer.

Because of the differential type of variables, various methods were adopted to measure the strength of the links between them - for binary and integer pairs of variables, the linear Pearson's correlation was used. Additionally, three measures Cramer's V measure of association (for pairs of integer variables), the Yule phi measure of correlation (for pairs of binary variables) and the Eta coefficient (for pairs of which one is a real constant variable and the other is an integer variable) - were adopted. Cramer's V and Eta have a value range of $<0$ and $1>$ and measure the relation strength, whereas Yule phi has a value range of $<-1$ and $1>$ and enables both the strength and the direction of the relations to be interpreted. All of these measures, excluding the Eta coefficient, are symmetric measures, meaning that the value of the relationship for the pair of variables $(X, Y)$ is the same as for the pair $(Y, X)$. The Eta coefficient is not a symmetric measure, so it is crucial which of the variables in the pair is dependent and which is independent. The relationships between research variables are presented in Table 4. Because of the differential variable types, not all of the slots are occupied.

A positive value means that an increase in one of the variables leads to the increase in the other variable, whereas a negative value represents the inverse relationship. For instance, the adoption of a pyramidal structure is positively associated with the company size and the value of its equity. Financial measures are correlated but this does not affect their explanatory importance. The lowest correlation is noted between the adoption of a pyramidal structure and the engagement of portfolio-oriented financial investors (Eta coefficient at 0.26 ). The explanatory variables reveal even weaker relationships - for example in the case of ALARGSHARE, ASSETSCON pair. Because of the sample characteristics, we could not test whether the value of measures is significantly different from zero.

\section{The econometric model}

We construct the linear panel model for the period 2010-2014, testing for probability in order to explain the adoption of pyramidal structures. The parameters of the fixed effect model are estimated with the use of the least square method. The explained variable of PYRAMID shows an increase or decrease for the adoption of pyramidal structures as an effect of the increase or decrease in the values of explanatory variables. The explanatory variables were chosen in order to provide an interpretation of their relations with the dependent variables and to ensure an acceptable error level for the estimated parameters. The final set of variables reveals the scores of the accuracy of the parameters estimation. The results of the analysis conducted with the use of open source gretl software are presented in Table 5 .

All structural parameters are estimated with the acceptable level of accuracy. In total, the changes in nine explanatory variables represent approximately $40 \%$ of variations in the probability of the adoption of a pyramid. We do not observe 
TABLE 5: Model tabulations for dependent variable: PYRAMID.

\begin{tabular}{|c|c|c|c|c|c|}
\hline Variable & Coefficient & Std. error & $t$-ratio & $p$ & Significance \\
\hline Const & -0.250949 & 0.0953995 & -2.6305 & 0.0087 & $* * *$ \\
\hline SUPBOARD & 0.091188 & 0.0135058 & 6.7518 & $<0.0001$ & $* * *$ \\
\hline BUSGROUP & 0.175029 & 0.0485839 & 3.6026 & 0.0003 & $* * *$ \\
\hline COMPS & -0.005956 & 0.0014924 & -3.9913 & $<0.0001$ & $* * *$ \\
\hline LARGSHARE & 0.017044 & 0.0021285 & 8.0074 & $<0.0001$ & $* * *$ \\
\hline ALARGSHARE & -0.010287 & 0.0020714 & -4.9664 & $<0.0001$ & $* * *$ \\
\hline FINPORTSHARE & -0.008503 & 0.0023822 & -3.5697 & 0.0004 & $* * *$ \\
\hline ASSETSCON & $5.888 \mathrm{e}-05$ & $2.227 e-05$ & 2.6432 & 0.0084 & $* * *$ \\
\hline TOTEQCON & -0.000150 & $4.161 \mathrm{e}-05$ & -3.6118 & 0.0003 & $* * *$ \\
\hline
\end{tabular}

***, $p<0.01$ Std. error; PYRAMID, adoption of a pyramid (1-yes, 0-no); SUPBOARD, the size of the supervisory board; BUSGROUP, represents that functioning within the business group (1-yes, 0 -no); COMPS, the number of firms in business group; LARGSHARE, represents the stake of the first largest shareholder (\%); ALARGSHARE, represents the stake of the first largest shareholder in case of a coalition (\%); FINSHARE, the stake of financial investors (\%): FINPORTSHARE, the stake by portfolio-oriented financial investors (\%); ASSETSCON, company assents (in million PLN); TOTEQCON, company equity (in million PLN).

auto-correlation or multi-linearity of explanatory variables in the constructed model. We run tests which support the use of the fixed effect model.

The parameters of the qualitative variables which measure the adoption of the pyramidal structures are interpreted within propensity and utility interpretations of probability. According to the propensity interpretations of probability, the goal of modelling is to identify the inclination of the unit to make decisions resulting in the dependent variable attaining the value of 1 (here the adoption of a pyramidal structure in a company). According to the utility interpretation of probability, the model measures the likelihood of the case that the adoption of the pyramidal structure affords a higher utility as opposed to the case of non-adoption of the pyramidal structure. The value of the structural parameters of the constructed model of the regressors of SUPBOARD, BUSGROUP, LARGSHARE, FINSHARE and ASSETSCON was estimated as positive. These results indicate that increases in the value of these variables increase the chances that a company adopts a pyramidal structure. The negative values for the parameters of COMPS, ALARGSHARE, FINPORTSHARE and TOTEQCON indicate that an increase in these company characteristics lowers the chances for adopting a pyramidal structure.

\section{Discussion}

The analysis of the sample of 168 non-financial Polish listed companies for the period of 2010-2014 provides descriptive statistics and the verification of the hypotheses to explain the emergence of pyramidal structures. These results add to our understanding of the ownership and control arrangements and contribute to explaining the formation of pyramids in listed companies (Almeida \& Wolfenzon 2006; Renneboog 1998). As the descriptive statistics demonstrate, the sample companies reveal a significant ownership concentration, estimated at $39 \%$ of shares controlled by the largest blockholder. The concentration rises to $42 \%$ in the case of shareholder coalitions. This finding is consistent with earlier studies on CEE in general (Bedo \& Acs 2007) and on Poland in particular (Aluchna 2007). Over half of the companies in the sample adopt a pyramidal structure, revealing the importance and popularity of this dynamically emerging ownership pattern. Poland is placed amongst numerous developed countries (Morck 2004) and emerging markets (Ramachandran \& Marisetty 2009; Su 2015), where pyramids appear to be a popular form of ownership. Interestingly, the adoption of a pyramidal structure is more popular than the use of dual class shares occurring in $10 \%$ of sample companies, which remains in line with previously conducted research on other countries (Almeida \& Wolfenzon 2006; Holmen \& Högfeldt 2005; Zattoni 1999). The pyramids identified in Poland comprised of basic, typically three-tier, structures, which make them relatively small and uncomplicated forms in comparison with their peers in Western Europe or Asia (Morck 2005; Morck et al. 2004).

We test three alternative rationales for explaining the formation of pyramids, including the notions of control leverage, venture and governance. The findings of the panel model reveal a number of observations on the company characteristics which determine the use of pyramids. Firstly, testing for the control leverage motivation, we note the positive link between the adoption of a pyramid and higher ownership concentration, which does not support hypothesis H1. Additionally, the adoption of a pyramid is also associated with lower ownership concentration by a shareholder coalition, which does not support hypothesis $\mathrm{H} 2$ either. A pyramid, as viewed in the literature as the mechanism of control leverage (Villalonga \& Amit 2006) and the separation of control and cash flow rights (i.e. participation in profit) (Claessens et al. 2002), should allow for maintenance of control while lowering the engaged capital at the same time. This is not the case in our study, as combining pyramids and ownership concentration questions this line of argument as both mechanisms have the opposite effect (Morck 2009). These findings suggest that we should reject the control leverage rationale which views the separation of control and cash flow rights as the main driver for the use of pyramidal structures. Our results show that shareholders in a pyramid maintain their investments at a higher proportion than would make rational sense for control leverage. Additionally, they are not interested in fragmenting their ownership stake and forming coalitions (Bianchi \& Bianco 2006) to minimise personal investment (Bebchuk et al. 2000; Villalonga \& Amit 2006). This finding is consistent with the observation that 
some pyramid-controlled firms reveal a minor separation between cash flow and votes. Almeida and Wolfenzon (2006:2641) argue that '(...) pyramidal structures with small deviations are more likely to appear in poor investor protection countries' which is the case of post-transition and emerging economies such as Poland.

In testing for the venture rationale, we reveal a positive relationship between the adoption of a pyramid and company operation within a business group (supporting hypothesis H3) as well as a smaller number of affiliated companies (supporting hypothesis H4). We argue that these observations indicate that pyramids are likely to be used to expand within the business groups, which provide easier access to finance and enable the founding of new ventures. These findings are consistent with the venture notion (Almeida et al. 2011; Almeida \& Wolfenzon 2006). They suggest that pyramidal structures become a tool for expansion of the business group, an important factor in an environment of costly access to external capital (Almeida et al. 2011). The arrangements of a business group provide access to funds on the internal capital market and lower the risk of the new venture (Demsetz \& Lehn 1985; Khanna \& Yafeh 2005; Kornbluth \& Salkin 1994). This finding corresponds with the arguments by Almeida and Wolfenzon (2006:2640), who note that the pyramidal structure is chosen by a company 'because of the payoff and financing advantages it provides when new firms are expected to yield low-security benefits relative to the required investments'. Companies which adopt pyramids are able to enjoy all these benefits within the more complex organisational structure of a business (corporate) group (Radygin 2007), which appears to be particularly important in transition and emerging economies.

Finally, we test for the governance rationale and identity that the adoption of a pyramid is associated with investment by financial investors (supporting H5), which we interpret as the use of a founding financial intermediary by the controlling shareholder, who constructs the pyramid in order to avoid a direct ownership involvement. Interestingly, the ownership stake of portfolio-oriented financial investors is inversely related to the adoption of a pyramid, as is consistent with hypothesis H6. We argue that this finding is consistent with the governance rationale (Edwards \& Weichenrieder 2004). Portfolio-oriented financial investors are likely to avoid excessive control by the blockholders. They anticipate the possible costs and shortcomings of the pyramidal structure (Villalonga \& Amit 2009) attributed to the risk of expropriation by large shareholders who may extract private benefits.

In summary, we believe that the evidence from Polish listed companies may explain the rationale for pyramid adoption in the context of emerging markets. This may have practical implications for understanding the motivation of entrepreneurs and company founders to use pyramids in order to secure growth and expand their companies. Further research could look for possible differences in motivation for pyramid use in developed and developing economies. One single rationale may not explain the adoption of pyramids worldwide.

\section{Conclusion}

This article sheds lights on the frequency and adoption of pyramidal structures and fills a gap in the existing literature on ownership and control in the context of emerging markets. We aim to identify the popularity of pyramids with listed companies and their adoption with the reference to three main perspectives. Firstly, we link the adoption of pyramids to ownership concentration and shareholders' coalitions with a rationale of separating cash flow and control rights, that is minimising capital investment while retaining control over the company. The second alternative explanation assumes that pyramids provide a device for the development of new companies within a business group that provides access to capital and enables founding new ventures under a weak institutional environment. Finally, the third perspective emphasises the efficient governance and lower transaction costs via the control of a financial entity accompanied by lower investment from portfoliooriented financial investors.

Our evidence indicates that pyramids are an important ownership and control arrangement. Pyramids are adopted by over $50 \%$ of sample companies and remain a more popular control mechanism than dual class shares. Their adoption is related to a larger ownership concentration by the first largest blockholder, lower concentration by a shareholder coalition, operation within a business group of a lower number of affiliated companies, as well as a larger investment of financial investors with a smaller stake controlled by portfolio-oriented financial investors. Consequently, we do not observe the motivation to separate cash flow and control rights as the main driver for adopting pyramids. Our findings support the venture approach, which views pyramids as a device for establishing new companies within a business group. Pyramidal structures become a tool for expansion of the business group, important in an environment of costly access to external capital because the business group enables the raising of capital and lowers the risk posed to a new firm. Finally, governance in a pyramid by financial entities discourages investment by portfolio-oriented financial investors.

This research reveals several limitations. Our results are based on a panel model over a 5-year period, while a wider time span would help address the dynamic evolution and persistence of pyramids in Poland. Moreover, the ability to analyse the emergence of pyramids in other Central and Eastern European countries would give us the opportunity to relate our results to the wider context of emerging markets.

\section{Acknowledgements Competing interests}

The authors declare that they have no financial or personal relationships which may have inappropriately influenced them in writing this article. 


\section{Authors' contributions}

M.A. formulated the conceptual framework and collected data. T.K. made the econometric calculations. Both M.A. and T.K. conducted the interpretation and discussion of the results.

\section{References}

Almeida, H., Park, S.Y., Subrahmanyam, M. \& Wolfenzon, D., 2011, 'The structure and formation of business groups: Evidence from Korean chaebols', Journal of Financial Economics 99(2), 447-475. https://doi.org/10.1016/j.jfineco.2010.08.017

Almeida, H. \& Wolfenzon, D., 2006, 'A theory of pyramidal ownership and family business groups', Journal of Finance 61(6), 2637-2680. https://doi.org/10.1111/ j.1540-6261.2006.01001.x

Aluchna, M., 2007, 'Does good corporate governance matter? Best practice in Poland' Management Research News 32(2), 185-198. https://doi.org/10.1108/01409 170910927631

Balcerowicz, L., 1995, Polskie Reformy Gospodarcze [Economic reforms in Poland], Polskie Wydawnictwo Naukowe, Warszawa.

Bany-Ariffin, A., Nor, F. \& McGowan, C., 2010, 'Pyramidal structure, firm capital structure exploitation and ultimate owners' dominance', International Review of Financial Analysis 19, 151-164. https://doi.org/10.1016/j.irfa.2010.03.002

Barontini, R. \& Caprio, L., 2006, 'The effect of family control on firm value and performance. Evidence from continental Europe', European Financial Management 12, 689-723. https://doi.org/10.1111/j.1468-036X.2006.00273.x

Bebchuk, L.A., Kraakman, R. \& Trantis, G., 2000, 'Stock pyramids, cross ownership and dual class equity: The mechanisms and agency costs of separating control from cash flow rights', in R. Morck (ed.), Concentrated ownership structure, pp. 295-318, University of Chicago Press Chicago, IL.

Bedo, Z. \& Acs, B., 2007, 'The impact of ownership concentration, and identity on company performance in the US and in Central and Eastern Europe', Baltic Journa of Management 2(2), 125-137. https://doi.org/10.1108/17465260710750955

Berglöf, E. \& Claessens, S., 2006, 'Enforcement and good corporate governance in developing countries and transition economies', World Bank Research Observer 2(1), 123-150. https://doi.org/10.1093/wbro/lkj005

Bertrand, M., Mehta, P. \& Mullainathan, S., 2002, 'Ferreting out tunnelling: An application to Indian business groups', Quarterly Journal of Economics 117 121-148. https://doi.org/10.1162/003355302753399463

Bianchi, M. \& Bianco, M., 2006, Italian corporate governance in the last 15 years: From pyramids to coalitions?, ECGI Working Paper No. 144, viewed 15 January 2017, from http://ecgi.global/sites/default/files/working_papers/documents/ SSRN-id952147.pdf

Bunkanwanicha, P., Fan, J. \& Wiwattanakantang, Y., 2008, 'The value of family networks: Marriage and network formation in family business groups', viewed 15 January 2017, from http://ssrn.com/abstract $=1108642$

Carlin, W. \& Mayer, C., 2003, 'Finance, investment and growth', Journal of Financial Economics 69(1), 191-226. https://doi.org/10.1016/S0304-405X(03)00112-0

Castañer, X. \& Kavadis, N., 2013, 'Does good corporate governance prevent bad strategies? An empirical analysis of non-value creating financial diversification in French companies, 2000-2006', Strategic Management Journal 34(7), 863-876. https://doi.org/10.1002/smj.2040

Claessens, S., Djankov, S., Fan, J.P.H. \& Lang, H.P., 2002, 'Disentangling the incentive and entrenchment effects of large shareholdings', Journal of Finance 57(6), 2741-2771. https://doi.org/10.1111/1540-6261.00511

Clarke, T., 2014, 'The impact of financialization on international corporate governance: The role of agency theory and maximizing shareholder value', Law and Financial Markets Review, 8(March), 39-51.

Coffee, J., 1999, 'Privatization and corporate governance: The lessons from securities market failure', Journal of Corporation Law 25, 1-39. https://doi.org/10.2139/ ssrn.190568

Combs, J., 2008, 'Commentary: The servant, the parasite, and the enigma: A tale of three ownership structures and their affiliate directors', Entrepreneurship Theory andPractice32(6),1027-1033.https://doi.org/10.1111/j.1540-6520.2008.00270.x

Cuervo-Cazzura, A., 2006, 'Business groups and their types', Asia Pacific Journal of Management 23(3), 419-437.

Demsetz, H., 1983, 'The structure of ownership and the theory of the firm', Journal of Law and Economics 26(2), 375-390. https://doi.org/10.1086/467041

Demsetz, H. \& Lehn, K., 1985, 'The structure of corporate ownership: Causes and consequences', Journal of Political Economy 93(3), 1155-1177. https://doi.org/ $10.1086 / 261354$

Dobak, M., 2006, 'Corporate governance in Central and Eastern Europe', Society and Economy 28(1), 27-40. https://doi.org/10.1556/SocEc.28.2006.1.2

Edwards, J. \& Weichenrieder, A., 2004, How weak in the weakest-link principle? On measurement of firm owners' control rights, CESIFO Working Paper no. 1255, Category 9: Industrial Organizations, CESifo Group, Munich.

Fama, E. \& Jensen, M., 1983, 'Separation of ownership and control', Journal of Law and Economics 26(2), 301-325. https://doi.org/10.1086/467037

Hardi, P. \& Buti, K., 2012, 'Corporate governance variables: Lessons from a holistic approach to Central-Eastern European practice', Corporate Governance 12(1), 101-117. https://doi.org/10.1108/14720701211191364
Harris, M. \& Raviv, A., 1988, 'Corporate governance. Voting rights and majority rights' Journal of Financial Economics 20(1-2), 203-235. https://doi.org/10.1016/0304405X(88)90045-1

Holmen, M. \& Högfeldt, P., 2005, 'Pyramidal discounts: Tunneling or overinvestment?', International Review of Finance 9(1-2), 133-175. https://doi.org/10.2139/ssrn. 667743

Jensen, M. \& Meckling, W., 1976, 'Theory of the firm: Managerial behavior, agency costs and ownership structure', Journal of Financial Economics 3(4), 305-60. https://doi.org/10.1016/0304-405X(76)90026-X

Khanna, T. \& Yafeh, Y., 2005, Business groups in emerging markets, Working Paper No. 92, European Corporate Governance Institute, viewed 10 December 2016, from http://ecgi.global/sites/default/files/working_papers/documents/SSRNid787625.pdf

Kornbluth, J. \& Salkin, G., 1994, 'The effects of marginal changes of ownership on multi-level objectives in corporate groups', Managerial and Decision Economics 15(1), 39-47. https://doi.org/10.1002/mde.4090150105

Le, S., Kroll, M. \& Walters, B., 2010, 'The impact of institutional changes on corporate governance mechanisms in transition economies', Journal of Management and Governance 14(2), 91-114. https://doi.org/10.1007/s10997-008-9075-4

Lio, G. \& Sun, P., 2004, 'Can corporate performance variations be explained by different intermediate control agents in stock pyramids? Evidence from Chinese public corporations', viewed from http://ssrn.com/abstract=507642, December 10, 2016.

Ministry of Treasury, 2016, Ocena przebiegu prywatyzacji [The assessment of privatization schemes], 1990-2015, viewed 09 December 2016, from https://bip. $\mathrm{msp}$. gov.pl/bip/raporty-analizy/ocena-przebiegu-prywaty.

Morck, R., 2004, 'How to eliminate pyramidal business groups - The double taxation of inter-corporate dividends and other incisive uses of tax policy', Tax Policy and the Economy 19, 135-179. https://doi.org/10.3386/w10944

Morck, R., 2005, A history of corporate governance around the world: Family business groups to professional managers, University of Chicago Press, Chicago, IL.

Morck, R., 2009, 'The riddle of the great pyramids', in A.M. Colpan, T. Hikino \& J.R. Lincoln (eds.), The Oxford Handbook of Business Groups, pp. 602-628, Oxford University Press, Oxford.

Morck, R., Wolfenzon, D. \& Yeung, B., 2004, 'Corporate governance, economic entrenchment and growth', Journal of Economic Literature 43(3), 655-720.

Murrell, P., 1999, 'Evolution in economics and in the economic reform of the centrally planned economics', in C. Clauge \& G. Rausser (eds.), The emergence of market economies in Eastern Europe, pp. 35-54, Blackwell, Cambridge.

Paskhaver, A. \& Verkhovodova, L., 2007, 'Privatization before and after the orange revolution', Problems of Economic Transition 50(3), 5-40. https://doi.org/10.2753/ PET1061-1991500301

Patel, S., Balic, A. \& Bwakira, L., 2002, 'Measuring transparency and disclosure at firmlevel in emerging markets', Emerging Market Review 3(4), 310-324. https://doi. org/10.1016/S1566-0141(02)00040-7

Perkins, S., Morck, R. \& Young, B., 2014, 'Innocents abroad: The hazards of international joint ventures with pyramidal group firms', Global Strategy Journal 4, 310-330. https://doi.org/10.1002/gsj.1087

Pursey, P., Heugens, P. \& Zyglidopoulos, S., 2008, 'From social ties to embedded competencies: The case of business groups', Journal of Management and Governance 12(4), 325-341. https://doi.org/10.1007/s10997-008-9064-7

Radygin, A., 2007, 'Corporate governance, integration and reorganization: The contemporary trends of Russian corporate groups', Econ Change 39, 261-323. https://doi.org/10.1007/s10644-007-9012-6

Ramachandran, K. \& Marisetty, V., 2009, 'Governance challenges for family controlled firms while globalizing', The Indian Journal of Industrial Relations 45(1), 54-61.

Renneboog, L., 1998, 'Shareholdings concentration and pyramidal ownership structures in Belgium: Stylized facts', Financial and Monetary Policy Studies 33, structures in Belgium: Stylized facts', Financial and Monetar
263-300. https://doi.org/10.1007/978-1-4757-2633-6_12

Renneboog, L., 2000, 'Ownership, managerial control and the governance of companies listed on the Brussels stock exchange', Journal of Banking and Finance 24, 1959-1995. https://doi.org/10.1016/S0378-4266(99)00128-4

Riyanto, Y. \& Toolsema, L., 2008, 'Tunneling and propping: A justification for pyramidal ownership', Journal of Banking and Finance 32, 2178-2187. https://doi.org/ 10.1016/j.jbankfin.2007.12.044

Ruszkowski, P., 2010, Oblicza polskiego konserwatyzmu. Wartości elit branżowych [The face of Polish conservatism. The values of industrial elites], UKSW Press, Warsaw.

Sauerwald, S. \& Peng, M., 2013, 'Informal institutions, shareholder coalitions, and principal-principal conflicts', Asia Pacific Journal of Management 30(3), 853-870. https://doi.org/10.1007/s10490-012-9312-x

Schulze, W., Lubatkin, M., Dino, R. \& Buchholtz, A., 2001, 'Agency relationships in family firms: Theory and evidence', Organization Science 12(2), 99-116. https:// doi.org/10.1287/orsc.12.2.99.10114

Shleifer, A. \& Vishny, R., 1997, 'A survey of corporate governance', Journal of Finance 52(2), 737-783. https://doi.org/10.1111/j.1540-6261.1997.tb04820.x

Su, K., 2015, 'The inner structure of pyramid and capital structure: Evidence from China', Economics: The Open-Access, Open-Assessment E-Journal 9, 1-31.https:// doi.org/10.5018/economics-ejournal.ja.2015-14

Urbanek, P., 2009, 'Struktura własności i kontroli w polskich spółkach publicznych w warunkach kryzysu gospodarczego [Ownership and control of Polish listed companies at the times of economic crisis]', in Nadzór korporacyjny a przedsiębiorstwo, pp 383-398,Gdańsk University, Gdańsk. 
Van Essen, M., Carney, M., Gedajlovic, E. \& Heugens, P., 2015, 'How does family control influence firm strategy and performance? A meta-analysis of US publicly listed firms', Corporate Governance: An International Review 23(1), 3-24. https:// doi.org/10.1111/corg.12080

Van Essen, M., Heugens, P., Van Oosterhout, H. \& Otten, J., 2012, 'An institution-based view of executive compensation: A multilevel meta-analytic test', Journal of International Business Studies 43(3), 396-423. https://doi.org/10.1057/jibs.2012.6

Villalonga, B. \& Amit, R., 2006, 'How do family ownership, management and control affect firm value', Journal of Financial Economics 80, 385-417. https://doi. org/10.1016/j.jfineco.2004.12.005
Villalonga, B. \& Amit, R., 2009, 'How are US family forms controlled?', The Review of Financial Studies 22(8), 3047-3091. https://doi.org/10.1093/rfs/hhn080

Wang, L. \& Judge, W., 2012, 'Managerial ownership and the role of privatization in transition economies: The case of China', Asia Pacific Journal of Management 29(2), 479-498. https://doi.org/10.1007/s10490-010-9205-9

Wooldridge, J.M., 2002, Econometric analysis of cross-section and panel data, The MIT Press, Cambridge.

Zattoni, A., 1999, 'The structure of corporate groups: The Italian case', Corporate Governance 7(1), 38-48. https://doi.org/10.1111/1467-8683.00127 